\title{
1927 NÜFUS SAYIMI SONUÇLARINA GÖRE ELAZIĞ NÜFUSU
}

\author{
1927 Census Results By Elaziğ Population
}

\section{Savaș SERTEL* \\ ÖZET}

Türkiye'nin ilk nüfus sayımı 1927 yılında yapılmıştır. 1927 yılında gerçekleştirilen nüfusu sayımı için 1926 yılında nüfus sayım kanunu çıkarılmıştır. Yine aynı yıl İstatistik Genel Müdürlüğü kurulmuş ve Belçikalı Camilla Jacquart kurumun başına getirilmiştir. 28 Ekim 1927 tarihinde ise Türkiye Cumhuriyet'inin ilk nüfus sayımı yapılmıştır. Sayım süresince sokağa çıkma yasağı uygulanmıştır. 1927 nüfus sayımında nüfusun çeşitli özellikleri ele alınmıştır. Bu çalışmada 1927 nüfus sayımı sonuçlarına göre Elazığ'da yaşayan nüfusun nitelikleri incelenmiştir. Bu sayım sonucuna göre Elazığ nüfusu 140.400 kişi'dir. İlin temel geçim kaynağı tarım ve hayvancılıktır. Meslekler itibarıyla il nüfusu incelendiğinde ilde uzun bir süre endüstrileşme yönünde bir gelişme olmayacağı da anlaşılmaktadır. 1927 yılında Elazığ'da okuryazarlık oranı $\% 4.85$ ’tir. Bu orana göre eğitim ve kültürel faaliyetlerin gelişmesi için de eğitim alanında daha fazla yatırım yapılması gerektiği ortaya çıkmaktadır. Kırsal nüfusun Türkiye ortalamasının üzerinde olması kentleşmenin uzun yıllar alacağını göstermektedir. Kısacası 1927 nüfus sayımında Elazığ ile ilgili veriler ilin içe kapalı bir ekonomik ve kültürel yapısı olduğunu, bunun kırılması için çok fazla yatırım gerekeceğini ortaya çıkmışır.

Anahtar Kelimeler: Elazığ Nüfusu, 1927 Nüfus Sayımı, Nüfus İstatistikleri.

\section{ABSTRACT}

Turkey's first census was conducted in 1927. To the population census conducted in 1927, the law was issued in 1926 census. Established in the same year was appointed head of the General Directorate of Statistics and Belgian Camille Jacquart institutions. In the October 28, 1927 made the first census of the Republic of Turkey. The curfew was applied during the census. Various characteristics of the population in the 1927 census were discussed. In this study, the characteristics of the population living in Elazı $\breve{g}$ were examined according to the 1927 census. According to the results of this census, the population of Elazı 140 400 persons. The basic livelihood of the province is agriculture and animal husbandry. As of the occupations examined provinces provincial population will be a long time in development is understood in terms of industrialization. In 1927, the literacy rate in Elazı $\breve{g} 4.851 \%$. For the development of educational and cultural activities according to this ratio also arises the need for greater investment in education. Turkey is above the average of the rural population shows will take many years of urbanization. In short, the 1927 census data on Elazig province's interior is a closed economic and cultural structure, for it appeared to be too much investment breakage.

Key Words: Elazig Population 1927 Census, Population Statistics.

\section{GİRIŞ}

1927 yılında yapılan nüfus sayımı Türkiye Cumhuriyeti'nin ilk nüfus sayımıdır. Bu nedenle bu ilk sayımdaki Türkiye nüfusu büyük bir önem arz eder. 1927 nüfus sayımı verileri cumhuriyetin ilk döneminde Anadolu şehirlerinin kuruluş döneminde hangi durumda olduğunu göstermesi açısından başlı başına irdelenmesi gereken bir istatistikî veri bütünüdür. Elazığ şehri ise tarih boyunca önemli yerleşim alanlarından biri olmuştur. Bol tatlı su kaynaklarına sahip olması, iklimi ve önemli ticaret yolları üzerinde bir kavşak noktası konumunda olması Elazığ'ın önemini daha da artırmıştır. 1927 yılı nüfus sayımına göre ilin nüfus verilerinin araştırılmamış olması ilin o dönemki sosyoekonomik yapısının tahlili açısından önemli bir eksikliğin giderilmesi anlamına gelir. Bu nedenle bu sayım verilerine göre Elazığ nüfusunun niteliklerinin incelenmesi bu çalışmanın konusunu teşkil etmektedir. Çalışmanın temel kaynağını Devlet İstatistik Enstitüsü tarafindan yayınlanan 1927 nüfus sayımı istatistikleri teşkil etmektedir. 1927 nüfus sayımı verileri ışığında Elazı ğ şehrinin o dönemki demografik ve sosyo-ekonomik yapısı incelenmiştir. Nüfus, hareket halinde, her an ve

\footnotetext{
* Yrd. Doç. Dr. Tunceli Üniversitesi Edebiyat Fakültesi Tarih Bölümü - TUNCELİ Mail: savassertel@mynet.com
} 


\section{F.Ü. Sosyal Bilimler Dergisi 2015-25/1}

durmadan değişen bir olaydır. Doğum ve ölüm gibi olaylar neticesinde dünyada yasayan insanların sayısı her an değiştiği gibi insanların yeryüzüne dağılışı da durmadan değişmektedir. Bu şekildeki bir değişimde elverişli coğrafî şartlara sahip olan yerleşmelerin nüfusu sürekli artarken, coğrafî potansiyelini yeterince kullanamayan yerleşmelerde nüfus sürekli azalmaktadır ${ }^{1}$. Nüfus sayımı, sınırları belli bir yerdeki nüfusun belli bir zaman diliminde sayılması işidir. Sayımlar nüfusun niceliğini ve niteliğini, yani büyüklügünü ve özelliklerini tanımayı sağlar. Nüfus sayımları demografinin temel veri kaynağıdır. Geçmiş dönemlerde nüfus sayımları oldukça masraflı ama kapsamlı bir bilgi edinme yöntemi olmuştur. Osmanlı döneminde yapılan nüfus sayımları askere alma ve vergi verecek kişilerin tespitini amaçlamıştır. Nüfus sayımları belli bir zaman diliminde nüfusun bütününe uygulandığı için bir fotoğraf olarak düşünülebilir. Genel nüfus sayımları öncelikle devlet yönetimini kolaylaştırmak için yapılmaktadır ${ }^{2}$. Nüfus sayımları, toplumu meydana getiren fertlerin sayı, cinsiyet, yaş, meslek, dil, din ve öğrenim durumlarını ortaya koyduğundan toplumların sosyolojik, ekonomik ve tarihi yönlerinin bilinmesi, sosyal tarihlerinin yazılması açısından oldukça önemlidir ${ }^{3}$.

Dünyada ilk sayımlar Çin'de (M.Ö. 3050), Sümer'de, Mısır'da (M.Ö. 2750), Hint Krallığı'nda, antik Yunan ve Roma'da yapılmıştır. Bu dönemdeki sayımlar bilimsel bir yönünden çok devletin daha iyi yönetilmesi kaygısı taşımıştır (askere alma ve vergilendirme). Bu amaçla haneler ve erkekler sayılmıştır. İslam dünyasında ilk nüfus sayımı hicretin ilk yılında Medine'de yapılmıştır. ${ }^{4}$ Buna göre 1.500 kişinin Müslüman olduğu tespit edilmiştir. Yenidünya olarak adlandırılan Amerika kıtasında ilk nüfus sayımı Kanada'da 1608'de kurulan Nouvelle France kolonisinde 1666 'da yapılmış ve bu sayım sonucu kolonide 3215 kişinin yaşadığ 1 tespit edilmişti. $\mathrm{Bu}$ sayımda herkesin adı, yaşı, cinsiyeti, mesleği ve medeni durumu da kayıtlara geçirilmiştir. ${ }^{5}$

Osmanlı'da ilk genel nüfus sayımı II. Mahmut devrinde 1830-1831 yıllarında yapılmıştır. Anadolu ve Rumeli'yi kapsayan bu sayım, yönetimin modernleşme ve merkezileşme çabalarının önemli bir ayağı ve göstergesi sayılabilir.

Batılı devletleri yakından takip eden yöneticiler bu devletlerin yaptırdığı nüfus sayımlarından istifade ettiklerini ve bu sonuçlara göre kaynakların daha verimli, daha isabetli kullanıldığını görerek Türkiye'de de bu yönde çalışmalara girişmiştir ${ }^{6}$. Bu amaçla1926 yılında "İstatistik Umum Müdürlüğü" kurulmuştur. Kurumun müdürlüğüne Uluslararası İstatistik Enstitüsü üyesi Belçikalı Camille Jacquart getirilmiştir ${ }^{7}$. Kurum ilk olarak 2 Haziran 1926'da nüfus sayımı hakkında 9 maddelik bir kanun çıkarmıştır ${ }^{8} .2$ Haziran 1926'da çıkarılan 896 Sayılı "İlk Genel Nüfus Sayımı Kanunu" TBMM tarafindan kabul edilmiş ve resmi gazetede yayınlanarak yürürlüğe girmiştir ${ }^{9}$. Bu kanun çıkarıldıktan sonra 28 Ekim 1927 tarihinde Türkiye'nin ilk genel nüfus sayımı yapılmıştır.

Doğu Anadolu Bölgesi'nde yer alan Elazığ, doğu ve kuzeydoğuda Bingöl, güneyde Diyarbakır, güneybatı ve batıda Malatya, kuzeybatıda Erzincan ve kuzeyde Tunceli illeri ile çevrilidir. 1927 yılı verilerine göre yüzölçümü $10.245 \mathrm{Km} 2$ 'dir. Elazı̆̆ su ve maden kaynakları ile verimli ovalara sahiptir. M.Ö. 6. Binden itibaren bölge en yoğun yerleşme alanlarındandır ${ }^{10}$. Elazığ'da Neolitik, Kalkolitik ve Paleolitik dönemlerden kalan yaşam izleri tespit edilmiştir. Elazı̆̆

\footnotetext{
${ }^{1}$ Ahmet Atasoy-M. Dursun Çitçi, “Elazığ Şehri’nin Nüfus Özellikleri ve Çevrenin Toplum Sağlığı Üzerindeki Etkisi”, Turkish Studies, C. 4/3 Bahar 2009, s. 198.

${ }^{2}$ Didem Danış, "Demografi: Nüfus Meselelerine Sosyolojik Bir Bakış", Ders Notları, s. 4.

${ }^{3} \mathrm{http}$ ://ataturkilkeleri.istanbul.edu.tr/wp-content/uploads/2013/03/ydta-12-dinc.pdf

${ }^{4}$ Muhammad Hamidullah, İslam Peygamberi, C. I, İrfan Yayınc1l1k, İstanbul 1995, s. 183.

${ }^{5}$ Mustafa Köse, 1927 Nüfus Sayımı ve Sonuçlarının Değerlendirilmesi, Afyon Kocatepe Üniversitesi Sosyal Bilimler Enstitüsü, Yayınlanmamış Yüksek Lisans Tezi, Afyonkarahiasr 2010, s. 5.

${ }^{6}$ Sami Yuca, "Cumhuriyet Döneminin İlk Nüfus Sayımına Göre Muş İlinin Nüfus Özellikleri.”, Akademik Bakış Dergisi, S. 24 (Nisan-Haziran) 2011, Celalabat-Kırgızistan, 2011, 9.

${ }^{7}$ Aytül Tamer-Alanur Çavlin Bozbeyoğlu, “ 1927 Nüfus Sayımının Türkiye’de Ulus Devlet İnşasındaki Yeri: Basında Yansımalar.”, Nüfusbilim Dergisi|Turkish Journal of Population Studies, 2004, S. 26, s. 74.

${ }^{8}$ Tamer-Bozbeyoğlu, A.g.m, s. 77.

${ }^{9}$ D.İ.E., 1965 Genel Nüfus Sayımı, İdari Bölünüs, 24 Ekim 1965, Ankara 1968, s. V; Yuca, Muş, s. 9.

${ }^{10}$ Yüksel Arslantaş, Tarih Öncesi Dönemde Elazığ, Elazı̆̆ 2013, s. 11-12.
} 
yöresi sahip olduğu su kaynakları, orman alanları, avlanabilecek hayvan türleri ve kendiliğinden yetişen yiyecek kaynaklarından dolayı Paleolitik dönemden başlayarak insan topluluklarının yaşam alanı haline gelmiştir ${ }^{11}$. İlin tarihine ait ilk yazılı bilgiler Hitit ve Asur tabletlerinden elde edilmiştir $^{12}$. Hititlerden sonra Urartu, Roma, Bizans ve Sasani hâkimiyetlerinde kalan Harput Hz. Ömer zamanında İslam orduları tarafindan fethedilmiştir ${ }^{13}$. Bir süre sonra tekrar Bizans eline geçen bölge 1085'te Çubuk Bey tarafindan zapt edilmiştir. Daha sonra yöre Artuklu, Selçuklu, Dulkadirli, Akkoyunlu ve Safevi hâkimiyetinde kalmıştır. Yavuz Sultan Selim zamanında Osmanlı topraklarına katılan Harput üç gün süren bir kuşatma sonucu 26 Mart 1516'da ele geçirilmiştir. Harput XIX. yüzyıldan itibaren stratejik açıdan önemini kaybetmiştir. Ulaşımın da zor olmasından dolayı Ağavat Mezraası denilen bu günkü yeri önem kazanmıştır. Vali İzzet Paşa zamanında mezranın adı dönemin padişahı Sultan Abdülaziz'e nispetle Mamûretülaziz'e çevrilmiştir. Yalnızca yeni kurulan şehrin değil teşkil edilen sancağın adı da bu şekilde anılmıştır. Mamuretülaziz Eyaleti 1867 vilayet nizamnamesinin uygulanmasıyla birlikte Diyarbakır Vilayetine bağlı bir sancak haline getirilmiştir. 1875 yılında ise müstakil bir mutasarrıflık yapılmıştır. 1879 'da vilayet olmuş ve bu statüsü cumhuriyet dönemine kadar devam etmiştir ${ }^{14}$.

Hititler döneminde Elazı̆̆ yöresi İşuwa olarak adlandırılmıştır. Harput yöresine milattan önceki dönemlerde Alzi ve Enzi'de denmiştir ${ }^{15}$. İslamiyet döneminde Harput'a Hısn-1 Ziyad olarak adlandırılmışıır' ${ }^{16}$. XIX. Yüzyılda Sultan Abdülaziz'e ithafen kullanılan Mamuratülaziz isminin uzun olmasından dolayı halk Elaziz demeye başlamıştır. 1937 yılı Kasım ayında Elaziz, Elazık’a (Azığı bol şehir) daha sonra 10 Aralık 1937'de Bakanlara Kurulu kararı ile de Elazığ'a çevrilmiştir ${ }^{17}$.

1310 Tarihli Mamuratül Aziz Salnamesinde Harput merkezinin nüfusu 30.639 kişidir. $^{18}$ Fransız gezgin Vital Cuinet'e göre Harput merkezinin nüfusu 20.000, Mezra nüfusu 5.000 ve Harput Sancağı'nın toplam nüfusu 295.704 kişidir. ${ }^{19}$ Şemsettin Sami'nin yazdığı Kamûsü'lalam adlı eserde Elazı̆̆'da 575.315 kişinin yaşadığı yazılmıştır. ${ }^{20} 1897$ Osmanlı nüfus sayımında Elazığ nüfusu 459.779 kişidir. Bu dönemde Mamuratülaziz'de 380.092 Müslüman, 958 Rum, 74.204 Ermeni, 2.390 Katolik, 607 Latin, 1.505 Eski Suriyeli, 21 Gayrimüslim Çingene, 1 Yahudi yaşamışı ${ }^{21}$.

Tablo 1. 1897 Osmanlı Nüfus Sayımına Göre Elazığ Nüfusu

\begin{tabular}{|l|l|l|l|l|l|l|l|l|l|c|c|}
\hline \multicolumn{2}{|c|}{ Müslüman } & \multicolumn{2}{c|}{ Rum } & \multicolumn{2}{c|}{ Ermeni } & Katolik-Protestan & \multicolumn{2}{c|}{ Latin } & \multicolumn{2}{c|}{ Eski Suriyeli } \\
\hline Erkek & Kadın & Erkek & Kadın & Erkek & Kadın & Erkek & Kadın & Erkek & Kadın & Erkek & Kadın \\
\hline 198.405 & 181.687 & 479 & 479 & 38.062 & 36.142 & 1.172 & 1.218 & 310 & 297 & 761 & 745 \\
\hline
\end{tabular}

Kaynak: Kemal Karpat, Osmanlı Nüfusu(1830-1914), Çev. Bahar Tırnakçı, Timaş yayınları, İstanbul 2010, s. 332.

Bunların dışında Mamuratülaziz'de yabancı uyruklu 59 kişi bulunmaktadır. 1900 yılında Mamuratülaziz Vilayeti'ne bağlı 14 kaza, 70 nahiye ve 1.890 köy vardır ${ }^{22} .1914$ Osmanlı nüfus sayımına göre Elazığ nüfusu 143.031 kişidir. Nüfusun 102.850'si Müslüman, 31.564'ü Ermeni, 5.585'i Protestan, 1.448'i Katolik Ermeni, 983'ü Süryani, 541'i Latin ve 60'1 Rum'dur ${ }^{23}$.

\footnotetext{
${ }_{11}^{11}$ Arslantaş, A.g.e, s. 249.

12 “Anabritannica, Elazı̆̆ Maddesi C. XI, İstanbul 1994, s. 161.

${ }^{13}$ Türkiye Diyanet Vakfi İslam Ansiklopedisi, Elazığ Maddesi C. X, İstanbul 2004, s. 551.

${ }^{14}$ Ahmet Aksın, 19. Yüzyılda Harput, Elazığ 1999, s. 75-76.

${ }^{15}$ Recep Yıldırım, "Harput/Elazı̆̆ Yöresinin Tarihi Coğrafyası”, Geçmişten Geleceğe Harput Sempozyumu(23-25 Mayıs 2013) Bildiri Kitabl, C. I, s. 300.

${ }^{16}$ Abdulgani Bulduk, El-Cezire'nin Muhtasar Tarihi, Yayına Hazırlayanlar: Mustafa Öztürk, İbrahim Yılmazçelik, Elazı̆ 2004, s. 61.

17 “Milli Eğitim Bakanlı̆̆ İslam Ansiklopedisi, Elazı̆̆ Maddesi C. IV, İstanbul 1979, s. 222.

${ }^{18} 1310$ Tarihli Mamuratül Aziz Vilayet Salnamesi

${ }^{19}$ Vital Cuinet, Turquie D'asie, Paris 1892, s. 352.

${ }^{20}$ Şemsettin Sami, Kamûsü'l-alam, Mihran Matbaası, İstanbul 1891, C. VI, s. 4333.

${ }^{21}$ Kemal Karpat, Osmanlı Nüfusu (1830-1914), Çev. Bahar Tırnakçı, Timaş yayınları, İstanbul 2010, s. 332.

${ }^{22}$ Karpat, s. 428.

${ }^{23}$ Karpat, s. 382-383.
} 
Tablo 2. 1914 Osmanlı Nüfus Sayımına Sonuçlarına Göre Elazı ̆̆ Nüfusu

\begin{tabular}{|l|l|l|l|l|l|l|l|}
\hline Bölgeler & Müslüman & Katolik Ermeni & Ermeni & Protestan & Süryani & Latin & Rum \\
\hline Mamurtalaziz & 56.365 & 1.323 & 23.725 & 4.000 & 344 & 374 & 23 \\
\hline Harput & 22.541 & 125 & 7.519 & 1.528 & 639 & 167 & - \\
\hline Keban & 23.944 & - & 320 & 57 & - & - & 37 \\
\hline Toplam & $\mathbf{1 0 2 . 8 5 0}$ & $\mathbf{1 . 4 4 8}$ & $\mathbf{3 1 . 5 6 4}$ & $\mathbf{5 . 5 8 5}$ & $\mathbf{9 8 3}$ & $\mathbf{5 4 1}$ & $\mathbf{6 0}$ \\
\hline
\end{tabular}

Kaynak: Kemal Karpat, Osmanlı Nüfusu(1830-1914), Çev. Bahar Tırnakçı, Timaş yayınları, İstanbul 2010, s. 382-383.

1914 ve 1927 nüfus sayımlarında Elazığ nüfusu birbirine çok yakın çıkmıştır. 1917 yılında Osmanlı Devleti'nde yapılan yabancı nüfus sayımında Elazığ'da 5 Alman, 3 Danimarkalı ve 1 İsviçreli olmak üzere toplam 9 yabancı bulunmaktadır. ${ }^{24}$

\section{Nüfus Yoğunluğu}

1927 Genel Nüfus Sayımına göre Türkiye' nin nüfusu 13.648.270 kişidir. Bu nüfusun \%24.2'si kentlerde, \%75.8'i ise kırsalda yaşamaktadır ${ }^{25}$. Elazı̆̆ nüfusunun ise \%18.6'sı kentlerde, \%81.4'ü kırsalda yaşamaktadır ${ }^{26}$. Kırsal nüfus Türkiye ortalamasını üzerinde, kentsel nüfus ise altında çıkmıştır. 1927 nüfus sayımında Elazı ̆̆ genelinde ve tüm ilçelerde kadın sayısı erkek sayısından fazladır. ${ }^{27}$ Kentsel nüfusa bakıldığında ise Keban hariç tüm ilçelerde ve Elazığ genelinde erkek sayısı kadınlardan fazladır. Kırsal nüfusta ise tüm ilçelerde ve il genelinde kadınlar erkeklerden fazladır. 1927 nüfus sayımı verilerine göre Elazı̆̆'da 140.400 kişi yaşamaktadır ${ }^{28}$. Nüfusun \%51.3'ü kadın, \%48.7'si erkektir. Nüfusun \%56.4'ü merkez ilçede, \%24.9'u Palu'da, \%9.1'i Baskil'de, \%7.1'i Maden'de ve \%2.4'ü Keban'da yaşamaktadır. Elazığ'da kentsel nüfus çok düşüktür. Zaten gelişmekte olan ve az gelişmiş ülkelerde kırlardan şehirlere göçün nedeni sanayileşme ile birlikte daha çok geçim sıkıntısına dayanmaktadır ${ }^{29}$. Bu dönemde Elazı ğ' daki kırsal nüfusun bu anlamda bir göçe ihtiyacı yoktur. Halk köylerde ekip biçerek uzun süre karnını doyurabilmektedir.

Tablo 3. 1927 Y1lı Genel Nüfus Sayımına Göre Elaziz'de Nüfus Yoğunluğu

\begin{tabular}{|l|l|l|l|l|l|l|}
\hline \multicolumn{1}{|c|}{ Yerleşim Yeri } & Erkek & Kadın & Toplam & Yüzölçümü $\left(\mathrm{km}^{2}\right)$ & $\begin{array}{c}\text { Nüfus } \\
\text { Yoğunluğu }\end{array}$ & $\begin{array}{c}\text { Mevaki } \\
\text { (Kayıp) }\end{array}$ \\
\hline Merkez & 38.884 & 40.330 & $\mathbf{7 9 . 2 1 4}$ & 3.225 & 24.6 & 304 \\
\hline Baskil & 5.949 & 6.856 & $\mathbf{1 2 . 8 0 5}$ & 2.094 & 10.4 & 116 \\
\hline Keban & 1.472 & 1.884 & $\mathbf{3 . 3 5 6}$ & 776 & 4.3 & 24 \\
\hline Maden & 4.973 & 5.046 & $\mathbf{1 0 . 0 1 9}$ & 1.340 & 7.5 & 85 \\
\hline Palu & 17.108 & 17.898 & $\mathbf{3 5 . 0 0 6}$ & 2.810 & 12.5 & 332 \\
\hline Toplam & $\mathbf{6 8 . 3 8 6}$ & $\mathbf{7 2 . 0 1 4}$ & $\mathbf{1 4 0 . 4 0 0}$ & $\mathbf{1 0 . 2 4 5}$ & $\mathbf{1 3 . 7 0}$ & $\mathbf{8 6 1}$ \\
\hline
\end{tabular}

Kaynak: BİUM, 1927 Umumi Nüfus Tahriri, Fasikül I, Hüsnütabiat Matbaası, Ankara 1929, s. VII; Başvekâlet Merkezi İstatistik Müdüriyeti Umumiyesi, 1927 Umumi Nüfus Tahriri, Türk Ocakları Merkez Heyeti Matbaası, Ankara 1928, s. 18.

\footnotetext{
${ }^{24}$ Nejdet Bilgi, “Osmanlı Devleti'nin 1917 Yılı Yabancı Nüfusu”, Tarih İncelemeleri Dergisi, C. XXV, S. I, Temmuz 2010 , s. 139.

${ }^{25}$ Koray Başol, Demografi(Genel ve Türkiye), İzmir 1984, s. 156.

${ }^{26}$ Başvekâlet Merkezi İstatistik Müdüriyeti Umumiyesi, 1927 Umumi Nüfus Tahriri, Türk Ocakları Merkez Heyeti Matbaas1, Ankara 1928, s. 18.

${ }^{27} \mathrm{Bu}$ durum Anadolu'nun geneli için geçerlidir. Osmanlı Devleti’nde 1911 yılında başlayan Tablusgarp Savaşı ile 11 yıl devam edecek olan aralıksız savaşlar dönemi başlayacaktır. 1922 yılına gelindiğinde Anadolu her şeyi ile tükenmiştir. En büyük kayıp ise eli silah tutan 15-45 yaş grubunda olmuştur. Bu nedenle tüm Anadolu'da kadın nüfusu erkek nüfusundan fazladir.

${ }_{28}$ BİUM, 1927 Umumi Nüfus Tahriri, Fasikül I, Hüsnütabiat Matbaası, Ankara 1929, s. VII; Başvekâlet Merkezi İstatistik Müdüriyeti Umumiyesi, 1927 Umumi Nüfus Tahriri, Türk Ocakları Merkez Heyeti Matbaası, Ankara 1928, s. 18.

${ }^{29}$ Yaşar Gök-Alperen Kayserili, “Cumhuriyet Döneminde(1927-2008) Erzurum İlinin Kır-Şehir Nüfus Değişimi.”, Doğu Coğrafya Dergisi, S. XXIV, s. 3.
} 
1927'de Türkiye'de km²,ye 17.89 kişi düşerken, Elazı ğ'da Km2'ye 13.70 kişi düşmektedir ${ }^{30}$. $\mathrm{Bu}$ oran Türkiye ortalamasına yakındır. Elazı̆̆' da yüzölçümü olarak en büyük ilçe merkez ilçedir. Merkez ilçeyi sırasıyla Palu, Baskil, Maden ve Keban izlemektedir. Nüfus yoğunluğu olarak ise yine merkez ilçe birinci sırada gelmektedir. Ardından Palu, Baskil, Maden ve Keban gelmektedir. Palu nüfus ve yüzölçümü olarak merkez ilçeden sonra Elazığ'ın en büyük ilçesidir. Keban ise yüzölçümü ve nüfus 1927 yılında Elazığ nüfusu Türkiye nüfusunun \%1.03'üne denk düşmektedir.

\section{Doğum Yeri İtibarıyla Nüfus}

1927 nüfus sayımı sonuçlarına göre Elazığ'da 79 Rusya, 52 Yunanistan, 37 Sırbistan, 23 bilinmeyen, 11 Almanya, 11 Avrupa, 5 Macaristan, 2 İran, 1 Bulgaristan, 1 Fransa ve 1 Amerika doğumlu insan vardır. Elazığ' da nüfusun \%0.1'i yurtdışı doğumludur (200 kişi). İlde Bulgaristan, Rusya, Sırbistan ve Yunanistan doğumlu insanların bulunmas1 1927 yılı itibarıyla sınırlı sayıda Balkan ve Rusya göçmeni yaşadığı sonucu çıkarmaktadır. ${ }^{31}$ Ancak ilde çok az sayıda göçmen vardır. Sınırlara yakın olmadığı için komşu illerde doğumlu olan insan sayısı da çok fazla değildir.

Tablo 4. 1927 Genel Nüfus Sayımı Verilerine Göre Elazığ’ da Doğum Yerleri İtibarıyla Nüfus

\begin{tabular}{|c|c|c|c|c|c|c|c|c|c|c|c|c|c|}
\hline Bölgeler & Cinsiyet & Türkiye & Almanya & Amerika & Avrupa & Bulgaristan & Macaristan & Rusya & Yunanistan & Sirbistan & İ̀n & Fransa & Bilinmeyen \\
\hline \multirow{3}{*}{ Merkez } & Erkek & 38.753 & 4 & 1 & 5 & 1 & - & 35 & 38 & 26 & 2 & 1 & 19 \\
\hline & Kadın & 40.251 & - & - & - & - & 5 & 44 & 14 & 11 & - & - & 4 \\
\hline & Toplam & 79.004 & 4 & 1 & 5 & 1 & 5 & 79 & 52 & 37 & 2 & 1 & 23 \\
\hline \multirow{3}{*}{ Maden } & Erkek & 4.960 & 7 & - & 6 & - & - & - & - & - & - & - & - \\
\hline & Kadın & 5.064 & - & - & - & - & - & - & - & - & - & - & - \\
\hline & Toplam & 10.024 & 7 & - & 6 & - & - & - & - & - & - & - & - \\
\hline \multirow{3}{*}{ Toplam } & Erkek & 68.242 & 11 & 1 & 11 & 1 & - & 35 & 38 & 26 & 2 & 1 & 19 \\
\hline & Kadın & 71.953 & - & - & - & - & 5 & 44 & 14 & 11 & - & - & 4 \\
\hline & Toplam & 140.195 & 11 & 1 & 11 & 1 & 5 & 79 & 52 & 37 & 2 & 1 & 23 \\
\hline
\end{tabular}

Kaynak: BİUM 1927 Umumi Nüfus Tahriri, s. 269-270.

Bu dönemde Elazığ' da yurt dışı doğumlu kişi sayısı çok azdır. 1927'de il göçmenler için cazibe merkezi bir özellik arz etmemektedir. Doğu'da yer alması ve gelişmiş bir sanayisinin bulunmamas1 1927'de ilde iş potansiyelinin çok kısıtlı olmasına sebep olmuştur. Bu nedenle yurt dışından gelen çok az insan ilde yerleşmiştir. Merkez ilçe ve Maden dışında hiçbir ilçede yurt dış1 doğumlu insan yaşamamaktadır. Bu durum özellikle ilçelerde kapalı toplum yapısının uzun süre korunmasina sebep olacaktır.

\section{Anadiller}

1927 nüfus sayımı sonuçlarına göre Türkiye'de 11,777,814 kişinin anadilinin Türkçe olduğu görülmüştür. Anadili Türkçe dışında bir dil olanların sayısı 1.870,465'tir. Bu nüfusun 1.184.446 kişisinin anadili Kürtçe'dir ${ }^{32}$. 1927 genel nüfus sayım sonucuna göre Elazığ' da en fazla konuşulan dil Türkçedir. İkinci sırada Kürtçe yer almaktadır. Nüfusun \%53.7'si Türkçe (75.358), \%44.9'u Kürtçe (63.047), \%1.3 (1.845)'i Ermenice, \%0.8'i diğer diller (94), \%0.01'i Arnavutça (21), \%0.01'i Arapça (15), \%0.01'i Çerkezce (8), \%0.01'i Rumca (8) ve 1 kişi de Fransızca konuşmaktadır. ${ }^{33}$ Türkçe, Kürtçe, Ermenice, Çerkezce dillerini konuşan kadın sayısı erkek sayısından fazladır. Arapça, Fransızca, Arnavutça ve Rumca konuşan erkek sayısı ise kadın sayısından fazladır.

\footnotetext{
${ }^{30}$ Başbakanlık İstatistik Umum Müdürlüğü, 1927 Umumi Nüfus Tahriri, Fasikül I, Hüsnütabiat Matbaası, Ankara 1929, s. XVII.

31 BİUM 1927 Umumi Nüfus Tahriri, s. 269-270. İlde Çerkezce konuşan nüfusun olması da bu ihtimali güçlendirmektedir.

32 Tamer-Bozbeyoğlu, A.g.m, s. 83.

${ }^{33}$ BIUUM 1927 Umumi Nüfus Tahriri, Fasikül I, Hüsnütabiat Matbaası, Ankara 1929, s. 233-234.
} 


\section{F.Ü. Sosyal Bilimler Dergisi 2015-25/1}

Tablo 5. 1927 Genel Nüfus Sayımı Sonuçlarına Göre Elazı ğ’da Konușulan Çeșitli Anadiller

\begin{tabular}{|c|c|c|c|c|c|c|c|c|c|c|}
\hline İlçeler & Cinsiyet & Türkçe & Arapça & Kürtçe & Çerkezce & Ermenice & Fransizca & Arnavutça & Rumca & $\begin{array}{c}\text { Diğer veya } \\
\text { Meçhul }\end{array}$ \\
\hline \multirow{3}{*}{ Merkez } & Erkek & 30.022 & 10 & 8.127 & 2 & 668 & 1 & 11 & & 42 \\
\hline & Kadın & 30.718 & 2 & 8.573 & - & 991 & - & 10 & & 34 \\
\hline & Toplam & 60.740 & 12 & 16.700 & 2 & 1.659 & 1 & 21 & 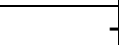 & 76 \\
\hline \multirow{3}{*}{ Baskil } & Erkek & 344 & - & 5.594 & - & 2 & & & 6 & 3 \\
\hline & Kadın & 336 & - & 6.515 & - & 5 & & & 7 & \\
\hline & Toplam & 680 & - & 12.109 & - & 7 & & & 6 & 3 \\
\hline \multirow{3}{*}{ Keban } & Erkek & 1.211 & - & 261 & - & - & & & & \\
\hline & Kadın & 1.459 & -1 & 425 & - & & & & & \\
\hline & Toplam & 2.670 & - & 686 & 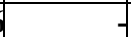 & - & & & - & \\
\hline \multirow{3}{*}{ Maden } & Erkek & 1.341 & 1 & 3.613 & - & 1 & & & 2 & 15 \\
\hline & Kadın & 1.111 & - & 3.931 & - & 4 & & & -1 & \\
\hline & Toplam & 2.452 & 1 & 7.544 & - & 5 & & & 2 & 15 \\
\hline \multirow{3}{*}{ Palu } & Erkek & 4.349 & 2 & 12.665 & - & 92 & & & & \\
\hline & Kadın & 4.467 & & 13.343 & 6 & 82 & & & & \\
\hline & Toplam & 8.816 & 2 & 26.008 & 6 & 174 & & & -1 & - \\
\hline \multirow{3}{*}{ Toplam } & Erkek & 37.267 & 13 & 30.260 & 2 & 763 & 1 & 11 & 8 & 60 \\
\hline & Kadın & 38.091 & 2 & 32.787 & 6 & 1.082 & & 10 & & 34 \\
\hline & Toplam & 75.358 & 15 & 63.047 & 8 & 1.845 & 1 & 21 & 8 & 94 \\
\hline
\end{tabular}

BïM 1927 Umumi Nüfus Tahriri, Ankara 1929, s. 233-234.

Türkçe Elazığ merkez ve Keban'da ilk sırada yer alırken, Kürtçe Baskil, Maden ve Palu'da en yaygın dildir ${ }^{34}$. Ermenice merkez ilçe ve Palu' da diğer ilçelere göre daha yaygın konuşulmaktadır. Elazı ̆̆ ve ilçelerinde az sayıda Arnavutça, Çerkezce ve Rumca konuşan bulunması 1927 yılı itibarıyla bölgede Balkan ve Kafkas göçmenlerinin olduğunu gösterir. En fazla dil çeşitliliği Elazı̆̆ merkezdedir.

Elazığ nüfusu konuşulan dil açısından ele alınırsa pek çok doğu ve güneydoğu ilinden farklı bir profil çizer. Doğu illerinde büyük bir kısmında ilk sırada yer alan anadil Kürtçe veya Zazaca'dır. ${ }^{35}$ Elazığ' da ise en fazla konuşulan anadil Türkçedir. Bu dönemde Elazı̆̆ da konuşulan dil çeşitliliği çok sınırlıdır. Dil çeşitliliği ile birlikte farklı dilleri konuşan insan sayısı da çok azdır. Bunda 1915 tehcir kanunu ve 1926 y1lında Yunanistan ile yapılan nüfus mübadelesinin de etkisi vardır. Ancak Müslüman unsurların konuştuğu dil sayısı da çok düşüktür. Osmanlı döneminde kozmopolit bir il olan Elazığ'da dil çeşitliliğindeki bu büyük azalma Cumhuriyet döneminde ilin dışa kapalı bir yapıya büründügünü ve ildeki farklı etnik yapıdaki Müslüman ahalinin de göç ettiğini gösterir.

\section{4. İnanç}

1927 Nüfus Sayımına göre Elazığ'da 138.337 Müslüman ve 2.000 gayrimüslim yaşamaktadır. Gayrimüslim nüfusun 1.999 kișisi Hıristiyan, 1 kiși ise Musevi'dir. 63 kiși ise farklı inançlardan$\mathrm{d}^{36}{ }^{36} .1927$ yılında gayrimüslim nüfus en fazla il merkezinde yaşamaktadır. İkinci sırada Palu,

\footnotetext{
${ }^{34}$ Maden ve Palu halkının anadili Kürtçe değil Zazacadır. Ancak 1927 nüfus sayımında bu ayrıma gidilmemiş, Zazaca da Kürtçe kategorisinde ele alınmıştır.

${ }^{35}$ Yuca, A.g.m, s. 17.

${ }^{36}$ BİUM 1927 Umumi Nüfus Tahriri, Fasikül I, Hüsnütabiat Matbaas1, Ankara 1929, s. 211-212.
} 
üçüncü sırada Maden ve dördüncü sırada Baskil yer almaktadır. Bu dönemde Keban'da gayrimüslim yaşamamaktadır.

Tablo 6. 1927 Genel Nüfus Sayımına Göre Elazı ğ'da Dinler ve Mezhepler

\begin{tabular}{|c|c|c|c|c|c|}
\hline İlçeler & Cinsiyet & İslam & Hiristiyan & Musevi & Diğer \\
\hline \multirow{3}{*}{ Merkez } & Erkek & 38.143 & 703 & 1 & 37 \\
\hline & Kadın & 39.226 & 1.079 & - & 25 \\
\hline & Toplam & 77.369 & 1.782 & 1 & 62 \\
\hline \multirow{3}{*}{ Baskil } & Erkek & 5.938 & 11 & - & - \\
\hline & Kadın & 6.853 & 3 & - & - \\
\hline & Toplam & 12.791 & 14 & - & - \\
\hline \multirow{3}{*}{ Keban } & Erkek & 1.472 & - & - & - \\
\hline & Kadın & 1.884 & - & - & - \\
\hline & Toplam & 3.356 & - & - & - \\
\hline \multirow{3}{*}{ Maden } & Erkek & 4.956 & 16 & - & 1 \\
\hline & Kadın & 5.043 & 3 & - & - \\
\hline & Toplam & 9.999 & 19 & - & 1 \\
\hline \multirow{3}{*}{ Palu } & Erkek & 17.019 & 89 & - & - \\
\hline & Kadın & 17.803 & 95 & - & - \\
\hline & Toplam & 34.822 & 184 & - & - \\
\hline \multirow{3}{*}{ Toplam } & Erkek & 67.528 & 819 & 1 & 38 \\
\hline & Kadın & 70.809 & 1.180 & - & 25 \\
\hline & Toplam & 138.337 & 1.999 & 1 & 63 \\
\hline
\end{tabular}

Kaynak: BİUM, 1927 Umumi Nüfus Tahriri, s. 211-212

1927 nüfus sayımı Osmanlı millet sistemine göre yapılmıştır. Bu sistemde halkın bir kısmı inancına göre tasnif edilirken bir kısmı ise etnik yapısına göre tasnif edilmiştir. Çalışmada bu yapı tabloya yansıtılmamıştır. Ancak buna da kısaca değinmekte fayda var. 1927 yılında Elazı ̆ nüfusu inanç itibarıyla şöyle tasnif edilmiştir: 138.337 Müslüman, 1.632 Ermeni, 167 Hıristiyan, 156 Ortodoks, 32 Katolik, 12 Protestan ve 1 Yahudi. Bu tasnifte bazı Huristiyanların mezhebe göre tasnifi yapılırken bazılarınınki yapılmamıştır. Yine Ermeni kategorisi vardır ki bu kategori inançtan çok etnik yapıyı ifade eder. Ayrıca XIX. Yüzyılda Harput yabancı kolejler aracılığıyla misyonerlik faaliyetlerinin çok yoğun olduğu bir ildir. Yapılan bazı yeni çalışmalarda emperyalist ülkelerin Osmanlı topraklarındaki Müslümanlardan çok gayrimüslimlere misyonerlik yaptığı iddia edilmektedir. Gerçekten de XIX. yüzyılda ve XX. yüzyıl başında Gregoryen mezhebinden olan Osmanlı Ermenilerinin önemli bir kısmı Protestan ve Katolik olmuştur. Elazı̆̆ geçmişte Ermenilerin yoğun olarak yaşadığı bir ildir. Ancak 1927 nüfus sayımına göre Elazığ’ da çok az Ermeni nüfusu çıkmıştır. Bu durum öncelikle 1915 Tehcir Kanunu ile Ermenilerin Anadolu dışına göç ettirilmesi ile açıklanabilir. Bunun yanı sıra I. Dünya Savaşı yıllarında Müslüman ve Ermeniler arasında ortaya çıkan huzursuzluklardan dolayı Ermenilerin yaşam koşulları daha iyi olan İstanbul ve İzmir gibi batı illerine göç etmiştir. Ayrıca ABD'nin o yıllarda Anadolu Ermenilerini özellikle de Harput Ermenilerini kendi ülkesine götürmesi gibi ${ }^{37}$ etkenler de etkili olmuştur. I. Dünya Savaş1

\footnotetext{
${ }^{37}$ ABD XIX. yüzyıldan itibaren Osmanlı Devleti'nde çeşitli misyoner okulları açmaya başlamıştır. Bunlardan biri de Harput'taki Fırat Koleji'dir. Bu kolejde özellikle farklı mezheplerdeki gayrimüslim çocukları Protestanlaştırılmaya çalışılmıştır. Bu okuldaki eğitimlerinin devamında hukuk, tıp ve mühendislik eğitimi almak için pek çok Ermeni genci ABD'ye götürülmüştür. Ayrıntı için bkz. Sinan Dinçer, “illk Gurbetçiler: Harput’tan ABD'ye Emek Göçü”, Geçmişten Geleceğe Harput Sempozyumu(23-25 Mayls 2013) Bildiri Kitabl, C. I, s. 309. Ayrıca bkz. Ahmet Aksın, 19. Yüzyllda Harput, Elazığ 1999, s.177-178.
} 


\section{F.Ü. Sosyal Bilimler Dergisi 2015-25/1}

sonrasında Fransa da önemli miktarda Ermeni’yi ülkesine kabul etmiştir. Osmanlı döneminde Elazığ'da Ermeni dışında çok miktarda gayrimüslim nüfus yaşamıştır. Ancak 1927 sayımında bu nüfusta da çok büyük bir azalma görülmüştür. Özellikle Rum nüfusunda çok büyük bir azalma görülmüştür. Bunun en önemli nedeni 1926'da Türkiye ile Yunanistan arasında yapılan nüfus mübadelesi olmuştur. ${ }^{38}$ Mübadeleden sonra Anadolu'da çok az Rum nüfusu kalmıştır.

\section{5. Özürlü Nüfus}

1927 nüfus sayımı sonuçlarına göre Elazığg'da 1.781 özürlü bulunmaktadır ${ }^{39}$. Özürlü nüfus toplam nüfusun \%1.3'ü oranındadır. Elazığg'da en fazla görülen sakatlıklar diğer kategorisidir (1.024). İkinci sırada körler (367), üçüncü sırada topallar (207), dördüncü sırada sağır-dilsizler (129), beşinci sırada çolaklar(41) ve son sırada kamburlar (23) yer alır. Elazığ'daki sakat nüfus ilçeler bazında ele alındığında merkez ilçe, Keban ve Maden'de kör, Keban'da topal, diğer sakatlıklar ve toplam özürlü sayılarında kadın sayısı erkeklerden fazladır. Maden'de kambur ve Palu'da çolak kategorisinde kadın ve erkek sayısı eşittir. Özürlü sayısı sırasıyla Elazığ merkez (1.247), Palu (272), Maden (137), Baskil (98) ve Keban (27)'da görülmüştür. Elazığ merkezde nüfusun \%1.6's1, Maden'de \%1.4'ü, Palu'da \%0.9'u, Keban'da \%0.8'i, Baskil'de \%0.8'i özürlüdür. Baskil ve Palu'da kambur, Keban'da ise kambur ve çolak yoktur.

Tablo 7. 1927 Nüfus Sayımı Sonuçlarına Göre Elazığ’da Özürlü Nüfus

\begin{tabular}{|c|c|c|c|c|c|c|c|c|c|}
\hline \multirow[b]{2}{*}{ İlçeler } & & \multicolumn{6}{|c|}{ Özür Türüne Göre Nüfus } & \multirow{2}{*}{$\begin{array}{c}\text { Özürlü } \\
\text { Nüfusun } \\
\text { Toplam Nüfusa } \\
\text { Oranı }\end{array}$} & \multirow[b]{2}{*}{$\begin{array}{c}\text { Toplam Özürli } \\
\text { Sayısı }\end{array}$} \\
\hline & & Çolak & Topal & Kör & $\begin{array}{l}\text { Sağır- } \\
\text { Dilsiz }\end{array}$ & Kambur & $\begin{array}{c}\text { Diğer } \\
\text { Sakatlıklar }\end{array}$ & & \\
\hline \multirow{3}{*}{ Elazı̆g } & Erkek & 27 & 122 & 118 & 58 & 16 & 498 & \multirow{3}{*}{$\% 1.6$} & 839 \\
\hline & Kadın & 8 & 55 & 141 & 37 & 5 & 162 & & 408 \\
\hline & Toplam & 35 & 177 & 259 & 95 & 21 & 660 & & 1.247 \\
\hline \multirow{3}{*}{ Baskil } & Erkek & 2 & 9 & 9 & 9 & - & 41 & \multirow{3}{*}{$\% 0.8$} & 70 \\
\hline & Kadın & 1 & 3 & 7 & 2 & - & 15 & & 28 \\
\hline & \begin{tabular}{|l|} 
Toplam \\
\end{tabular} & 3 & 12 & 16 & 11 & - & 56 & & 98 \\
\hline \multirow{3}{*}{ Keban } & Erkek & - & - & 6 & 2 & - & 4 & \multirow{3}{*}{$\% 0.8$} & 12 \\
\hline & Kadın & - & 1 & 8 & - & - & 6 & & 15 \\
\hline & \begin{tabular}{|l|} 
Toplam \\
\end{tabular} & - & 1 & 14 & 2 & - & 10 & & 27 \\
\hline \multirow{3}{*}{ Maden } & \begin{tabular}{|l|} 
Erkek \\
\end{tabular} & 1 & 6 & 7 & 13 & 1 & 63 & \multirow{3}{*}{$\% 1.4$} & 91 \\
\hline & Kadın & - & 4 & 10 & 5 & 1 & 26 & & 46 \\
\hline & \begin{tabular}{|l|} 
Toplam \\
\end{tabular} & 1 & 10 & 17 & 18 & 2 & 89 & & 137 \\
\hline \multirow{3}{*}{ Palu } & Erkek & 1 & 4 & 36 & 2 & - & 179 & \multirow{3}{*}{$\% 0.9$} & 222 \\
\hline & Kadın & 1 & 3 & 15 & 1 & - & 30 & & 50 \\
\hline & Toplam & 2 & 7 & 51 & 3 & - & 209 & & 272 \\
\hline \multirow{3}{*}{ Toplam } & Erkek & 31 & 141 & 186 & 84 & 17 & 785 & \multirow{3}{*}{$\% 1.3$} & 1.234 \\
\hline & \begin{tabular}{|l|} 
Kadın \\
\end{tabular} & 10 & 66 & 181 & 45 & 6 & 239 & & 547 \\
\hline & Toplam & 41 & 207 & 367 & 129 & 23 & 1.024 & & 1.781 \\
\hline
\end{tabular}

Kaynak: BİUM, 1927 Umumi Nüfus Tahriri, s. 221-222.

1927 yılında Elazı̆ genelinde tüm özürlü kategorilerinde erkeler kadınlardan fazladır. Bu duruma göre özürlülüklerin önemli bir kısmının sonradan olma ihtimali yüksektir. Çünkü bu dönemde kadınlar ev işleriyle uğraşırken tüm ağır işleri erkekler yürütmektedir. Ayrıca Osmanlı Devleti'nin 1911'den 1922 yılına kadar aralıksız olarak 11 yıl boyunca savaştığı da dikkate alınırsa erkek nüfusta neden daha fazla sakatlık görüldüğü daha da netleşecektir. Ayrıca 1925 yılında Doğu Anadolu Bölgesinde ortaya çıkan Şeyh Sait İsyanı'na katılan pek çok kişi vardır. ${ }^{40}$ İlde toplam özürlü sayısının il nüfusuna oranla çok az olması kalıtsal hastalıkların da fazla olmadığını göstermektedir. Doğuştan olma ihtimali en fazla olan özürlülük sağır-dilsizliktir. Bir kısmı topal ve çolak nüfusun oluşmasında ildeki sağlık hizmetlerinin yetersizliği etkilidir. Çünkü ildeki doğumların büyük bir kısmı evlerde ilkel koşullarda olmuştur. Doğumu gerçekleştiren bilinçsiz

\footnotetext{
${ }^{38}$ Lozan'da yer alan nüfus mübadelesi ancak 1926'da uygulanabilmiştir. Buna göre İstanbul ve Batı Trakya mübadeleye dâhil edilmemiştir. Bunun dışında Yunanistan ve Anadolu'daki Türk ve Rum nüfusu karşılıklı olarak değiştirilmiştir.

${ }^{39}$ BIUUM, 1927 Umumi Nüfus Tahriri, Fasikül I, Hüsnütabiat Matbaas1, Ankara 1929, s. 221-222.

${ }_{40}$ İsyana adını veren Şeyh Sait Elazığ'ın Palu ilçesi halkındandır. İsyan sırasında halkın bir kısmı Şeyh Sait’i desteklerken bir kısmı ise hükümeti desteklemiştir. Herk iki taraftan da çok sayıda ölüm, yaralanma ve sakatlık meydana gelmiştir.
} 
kişiler bazı çocukların doğarken sakatlanmasına neden olmuştur. 1927'de toplam nüfusun $\% 98,7^{\prime}$ 'sinin sağlıklı olması ülkede ihtiyaç duyulan kas gücüne dayalı çalışan ihtiyacı açısından büyük önem arz etmektedir.

\section{Medeni Hal}

1927 yılında yapılan sayımda Elazığ'da medeni hal durumuna göre en fazla nüfus bekâr kategorisinde bulunmaktadır. Bekâr sayısı evli sayısından 5.019 kişi fazladır. Buna göre Elazı̆ 1927 yılında genç nüfusun yoğun olduğu bir ildir. Bekâr nüfusta erkek sayısı kadın sayısından 4.190 kişi fazladır. Baskil dışındaki tüm ilçelerde bekâr erkek sayısı bekâr kadın sayısından fazladır. Evli nüfus Elazı ğ'da ikinci sırada yer alan medeni hal kategorisidir. Bu kategoride erkek sayısı kadın sayısından 1.724 kişi fazladır. İlçeler bazında evli nüfus ele alındığında ise merkez ve Baskil'de erkekler, Keban, Maden ve Palu'da kadınlar fazladır. ${ }^{41}$

Tablo 8. 1927 Nüfus Sayımı Sonuçlarına Göre Elazı ğ’ da Medeni Hal

\begin{tabular}{|c|c|c|c|c|c|c|}
\hline \multirow{2}{*}{ Bölge } & \multirow{2}{*}{ Cinsiyet } & \multicolumn{5}{|c|}{ Medeni Hal } \\
\hline & & Bekâr & Evli & Dul & Boşanmış & Bilinmeyen \\
\hline \multirow{3}{*}{ Merkez } & Erkek & 21.168 & 17.070 & 574 & 63 & 9 \\
\hline & Kadın & 16.405 & 16.942 & 6.697 & 285 & 1 \\
\hline & Toplam & 37.573 & 34.012 & 7.271 & 348 & 10 \\
\hline \multirow{3}{*}{ Baskil } & Erkek & 1.176 & 4.726 & 45 & 1 & 1 \\
\hline & Kadın & 3.749 & 2.659 & 423 & 23 & 2 \\
\hline & Toplam & 4.925 & 7.385 & 468 & 24 & 3 \\
\hline \multirow{3}{*}{ Keban } & Erkek & 917 & 531 & 23 & 1 & - \\
\hline & Kadın & 858 & 714 & 307 & 5 & - \\
\hline & Toplam & 1.775 & 1.245 & 330 & 6 & - \\
\hline \multirow{3}{*}{ Maden } & Erkek & 2.902 & 1.984 & 75 & 10 & 2 \\
\hline & Kadın & 2.235 & 2.029 & 718 & 45 & 1 \\
\hline & Toplam & 5.137 & 4.013 & 793 & 55 & 3 \\
\hline \multirow{3}{*}{ Palu } & Erkek & 9.353 & 7.464 & 266 & 5 & 20 \\
\hline & Kadın & 8.082 & 7.707 & 2.092 & 15 & 2 \\
\hline & Toplam & 17.435 & 15.171 & 2.358 & 20 & 22 \\
\hline \multirow{3}{*}{ Toplam } & Erkek & 35.516 & 31.775 & 983 & 80 & 32 \\
\hline & Kadın & 31.329 & 30.051 & 10.237 & 373 & 6 \\
\hline & Toplam & 66.845 & 61.826 & 11.220 & 453 & 38 \\
\hline
\end{tabular}

Kaynak: BİUM 1927 Umumi Nüfus Tahriri, Ankara 1929, s.167-168.

Dul nüfusta kadın sayısı erkek sayısından 10 kat fazladır. Dul sayısı en fazla merkez ilçede (7.271) görülmektedir. İkinci sırada Palu (2.092), üçüncü sırada Maden(714), dördüncü sırada Baskil (423) ve son sırada Keban (330) gelmektedir. Dul sayısında kadınların erkelere oranlar çok fazla çıkması o dönemin şartlarıyla alakalıdır. Balkan Savaşları, I. Dünya Savaşı, Kurtuluş Savaşı, Azınlık İsyanları, Şeyh Sait İsyanı gibi etkenler Anadolu'da binlerce genç erkeğin ölümüne sebep olmuştur.

Bu dönemde Elazı̆̆ genelinde 453 boşanma olmuştur. Boşanan nüfusun 373'ü kadın, 80'i erkektir. Boşanmış kadın sayısı erkek sayısının 4 katından fazladır. Elazı ̆’ da Boşanmış nüfus evli nüfusun $\% 0.73$ 'ü oranındadır. Boşanmış nüfusun en fazla olduğu ilçe merkez ilçesidir (348). İkinci sırada Maden (55), üçüncü sırada Baskil (24), dördüncü sırada Palu (20) ve son sırada Keban (6) gelmektedir.

\section{Okuryazarlık}

Bir ülkenin, bölgenin veya beldenin kalkınabilmesi için o bölgede yetişmiş, iyi eğitim almış, kaliteli bir öğrenim sürecinden geçmiş, bilinçli, girişimci ve kalifiye insanlara ihtiyaç vardır ${ }^{42}$. Bu nitelikteki insanları hedefleyen ülkelerin ise çok iyi bir eğitim sistemine, yüksek kalitede eğitim elemanı ve gereçlerine sahip olmalıdır. Nüfus sayımlarındaki okuryazarlık durumu ülkelere eğitim

\footnotetext{
${ }^{41}$ BİUM 1927 Umumi Nüfus Tahriri, Fasikül I, Hüsnütabiat Matbaası, Ankara 1929, s.167-168.

${ }^{42}$ Kara-Yuca, A.g.m, s. 196; Kodal, A.g.m, s. 245.
} 


\section{F.Ü. Sosyal Bilimler Dergisi 2015-25/1}

alanda yapılması gereken yatırımlar hakkında ipucu vermektedir. Ayrıca ülkelerin gelişmişlik kriterlerinden biri de nüfusun eğitim durumudur.

1927 Nüfus Sayımına göre Türkiye genelinde 1.111.496 kişi okuma yazma bilmektedir. 12.517.992 kişi ise okuma-yazma bilmemektedir. Bu oran Türkiye nüfusunun \% 8.16'sina denk düşmektedir. Okuryazar olmayanlar ise toplam nüfusun $\% 91.84$ 'ü oranındadır ${ }^{43}$. Elazı ğ'da okuryazar nüfus genel nüfusun $\% 4.85$ 'i oranındadır. Nüfusun $\% 95.15$ 'i okuryazar değildir ${ }^{44}$. Buna göre Elazığ'da okuryazar nüfus Türkiye ortalamasının altında, okuryazar olmayan nüfus ise Türkiye ortalamasının üzerindedir.

Tablo 9. 1927 Genel Nüfus Sayımına Göre Elazığ' da Okuryazarlık

\begin{tabular}{|c|c|c|c|}
\hline İlçe & Cinsiyet & Okuryazar Olan & Okuryazar Olmayan \\
\hline \multirow{3}{*}{ Merkez } & Erkek & 5.173 & 33.711 \\
\hline & Kadın & 578 & 39.752 \\
\hline & Toplam & 5.751 & 73.463 \\
\hline \multirow{3}{*}{ Baskil } & Erkek & 159 & 5.790 \\
\hline & Kadın & - & 6.856 \\
\hline & Toplam & 159 & 12.646 \\
\hline \multirow{3}{*}{ Keban } & Erkek & 158 & 1.314 \\
\hline & Kadın & 21 & 1.863 \\
\hline & Toplam & 179 & 3.177 \\
\hline \multirow{3}{*}{ Maden } & Erkek & 311 & 4.662 \\
\hline & Kadın & 38 & 5.008 \\
\hline & Toplam & 349 & 9.670 \\
\hline \multirow{3}{*}{ Palu } & Erkek & 364 & 16.744 \\
\hline & Kadın & 5 & 17.893 \\
\hline & Toplam & 369 & 34.637 \\
\hline \multirow{3}{*}{ Toplam } & Erkek & 6.165 & 62.221 \\
\hline & Kadın & 642 & 71.372 \\
\hline & Toplam & 6.808 & 133.593 \\
\hline
\end{tabular}

Kaynak: BİUM 1927 Umumi Nüfus Tahriri, s. 167-168.

$\mathrm{Bu}$ dönemde Elazığ genelinde okuryazar erkek sayısı okuryazar kadın sayısının 9.6 katı fazladır. Erkeklerde okuryazarlık genel nüfusun \%4.4'ü oranındadır. Kadınlarda ise \%0.5 oranındadır. 1927 nüfus sayımına göre Elazığ'da en fazla okuryazar nüfus merkezde bulunmaktadır. İkinci sırada Palu, üçüncü sırada Maden, dördüncü sırada Keban ve son sırada Baskil yer almaktadır. Kadınlar arasında okuryazarın en fazla olduğu yerleşim yeri yine il merkezidir. İkinci sırada Maden, üçüncü sırada Keban, dördüncü sırada Palu ve son sirada Baskil yer almıştır. Dördüncü sırada yer alan Palu'da okuryazar olan beş kadın bulunurken, son sıradaki Baskil'de okuryazar kadın bulunmamaktadır.

\section{Yaş grupları}

Dünya'da yapılan genel nüfus sayımlarında kadınların ve çocukların eksik sayılması en yaygın hatadır. Özellikle kırsal bölgelerde, doğum kayıtlarının geç tutulması ve doğanın ritmiyle bağlantılı zaman kavrayışından dolayı yaşların yanlış açıklanması sık rastlanılan bir hatadır. $\mathrm{Bu}$ hatalar nüfusun gerçek büyüklügünden daha fazla veya daha az çıkmasına neden olur. Yine Yeni doğanların veya ölenlerin kaydedilmemesi veya geç kaydedilmesi, anne-baba isimlerinin yanlış yazılması, kayıtların eksik tutulması da nüfus verilerinde eksiklik ve yanlışlıklara sebep olabilmektedir ${ }^{45}$. Kadın erkek sayıları genelde birbirine yakındır. Ancak savaşlar ve göçler bu dengeyi bozmaktadır. Cumhuriyetin ilk yıllarında nüfusu artırmaya yönelik bir devlet politikası benimsenmiştir. 1927 Nüfus Sayımı bu politika açısından da bir zemin niteliğindedir ${ }^{46} .1927$ nüfus sayımı verilerine göre Elazığ nüfusunun \%95.4'ü 61 yaş altını oluşturmaktadır. İlde çocuk nüfusu da çok

\footnotetext{
${ }^{43}$ Başbakanlık İstatistik Umum Müdürlüğü, 1935 Genel Nüfus Sayımı, Ankara 1937, s. 382.

${ }^{44}$ BïUM 1927 Umumi Nüfus Tahriri, Fasikül I, Hüsnütabiat Matbaas1, Ankara 1929, s. 167-168.

${ }^{45}$ Danış, A.g.e, s. 6, 21.

${ }^{46}$ Tamer-Bozbeyoğlu, A.g.m, s. 81.
} 
fazladır. Elazığ'da 0-12 yaş grubu 51.914 kişidir. Bu ise toplam nüfusun \%37'sine denk düşmektedir. Elazı '̆'da aktif nüfus yani eli iş tutabilecek olan faal nüfus olan 20-45 yaş grubunda 54.298 kişi vardır. Bu oran nüfusun \%38.7'sine denk düşmektedir ${ }^{47}$.

Tablo 10. 1927 Genel Nüfus Sayımına Göre Elazı ğ’ da Yaş Grupları

\begin{tabular}{|c|c|c|c|c|c|c|c|c|c|c|c|}
\hline \multirow[b]{2}{*}{ İlçeler } & \multirow[b]{2}{*}{ Cinsiyet } & \multicolumn{10}{|c|}{ Yaş Grupları } \\
\hline & & $\begin{array}{c}1 \\
\text { Yaşından } \\
\text { Küçük } \\
\end{array}$ & $\begin{array}{c}1-2 \\
\text { Yaş }\end{array}$ & $\begin{array}{l}3-6 \\
\text { Yaş }\end{array}$ & $\begin{array}{l}7-12 \\
\text { Yaş }\end{array}$ & $\begin{array}{c}13-19 \\
\text { Yaş }\end{array}$ & $\begin{array}{c}20-45 \\
\text { Yaş }\end{array}$ & $\begin{array}{c}46-60 \\
\text { Yaş }\end{array}$ & $\begin{array}{c}61-70 \\
\text { Yaş }\end{array}$ & $70+$ & Bilinmeyen \\
\hline \multirow{3}{*}{ Merkez } & Erkek & 1.999 & 3.782 & 4.297 & 4.506 & 5.682 & 13.729 & 2.873 & 1.451 & 530 & 36 \\
\hline & Kadın & 2.264 & 3.878 & 3.173 & 5.173 & 4.850 & 17.151 & 1.963 & 757 & 206 & 915 \\
\hline & Toplam & 4.263 & 7.256 & 7.470 & 9.679 & 10.532 & 30.880 & 4.836 & 2.208 & 736 & 951 \\
\hline \multirow{3}{*}{ Baskil } & Erkek & 110 & 966 & 801 & 954 & 916 & 1.605 & 294 & 226 & 76 & 1 \\
\hline & Kadın & 44 & 732 & 715 & 674 & 813 & 3.012 & 656 & 133 & 77 & - \\
\hline & Toplam & 154 & 1.698 & 1.516 & 1.628 & 1.729 & 4.617 & 950 & 359 & 153 & 1 \\
\hline \multirow{3}{*}{ Keban } & Erkek & 86 & 157 & 197 & 186 & 258 & 404 & 108 & 58 & 18 & - \\
\hline & Kadın & 76 & 138 & 186 & 129 & 284 & 780 & 196 & 58 & 37 & - \\
\hline & Toplam & 162 & 295 & 383 & 315 & 542 & 1.184 & 304 & 116 & 55 & - \\
\hline \multirow{3}{*}{ Maden } & Erkek & 237 & 618 & 543 & 455 & 933 & 1.652 & 338 & 142 & 49 & 6 \\
\hline & Kadın & 149 & 434 & 583 & 422 & 672 & 2.132 & 472 & 125 & 55 & 2 \\
\hline & Toplam & 386 & 1.052 & 1.126 & 877 & 1.605 & 3.784 & 810 & 267 & 104 & 8 \\
\hline \multirow{3}{*}{ Palu } & Erkek & 659 & 1.521 & 2.905 & 2.250 & 1.683 & 5.819 & 1.330 & 663 & 239 & 39 \\
\hline & Kadın & 484 & 1.355 & 2.507 & 1.607 & 1.673 & 8.005 & 1.652 & 414 & 180 & 21 \\
\hline & Toplam & 1.144 & 2.876 & 5.412 & 3.857 & 3.356 & 13.824 & 2.982 & 1.077 & 4.19 & 50 \\
\hline \multirow{3}{*}{ Toplam } & Erkek & 3.091 & 7.044 & 8.752 & 8.351 & 9.472 & 23.209 & 4.943 & 2.540 & 912 & 82 \\
\hline & Kadın & 2.973 & 6.537 & 7.164 & 8.005 & 8.292 & 31.080 & 4.939 & 1.487 & 555 & 938 \\
\hline & Toplam & 6.064 & 13.581 & 15.916 & 16.356 & 17.764 & 54.289 & 9.882 & 4.027 & 1.467 & 1.024 \\
\hline
\end{tabular}

Kaynak: BİUM, 1927 Umumi Nüfus Tahriri, s. 167-168.

20-46 yaş grubunda tüm ilçelerde ve il genelinde kadınlar erkeklerden fazladır. 20-45 yaş grubunda erkeklerin az olması Türkiye genelinde görülen bir durumdur. Bu durumu izah eden genel bir açıklama olmasa da savaşlardan yeni çıkmış olan bir ülkede yapılan nüfus sayımında erkeklerin az çıkması beklenen bir durumdur. Çünkü Türkiye'de sadece erkekler askerlikle mükelleftir.

\section{Meslek Grupları}

Bir bölgenin nüfusu ve istihdam durumu o bölgenin iktisadî gelişmesini değerlendirebilme yönünden büyük bir önem taşır. Bir başka deyişle, nüfus ve iş gücünün oluşum şekli ve artış1, kalkınan bir bölge için faydalanılabilecek bir araçtır ${ }^{48}$. Bir bölgede istihdam ve üretimin olabilmesi için nüfusun nitelikleri çok büyük bir önem taşımaktadır.

Anadolu nüfusunun büyük bir çoğunluğu yüz yıllardır tarım ve hayvancılık ile hayatını kazanmıştır. Coğrafi şartların getirdiği bu duruma siyasi faktörler de etkide bulunmuştur. Ekonomisi toprağa dayalı olan Osmanlı imparatorluğunda bir reayanın toprağını bırakıp gitmesi kanun gereği suç sayılmış ve cezalandırılmıştır ${ }^{49}$. Böyle bir ortamda Cumhuriyet'in ilk yıllarına kadar gelen süreçte Müslüman halk ticarete yeterince atılmamış ve bu alan gayrimüslimlere bırakılmıştır. Cumhuriyetin ilk yıllarına gelindiğinde Osmanlı'dan alınan bu ekonomik yapı aynı biçimde devam etmekteydi ${ }^{50}$. 1927 yılında tüm yurtta olduğu gibi Elazığ' da da en büyük geçim

${ }^{47}$ BİUM, 1927 Umumi Nüfus Tahriri, Fasikül I, Hüsnütabiat Matbaası, Ankara 1929, s. 167-168.

${ }^{48}$ Tahir Kodal, “Cumhuriyetin İlk Nüfus Sayımına Göre Denizli’nin Nüfus Yapısı”, Pamukkale Üniversitesi Eğitim Fakültesi Dergisi, Kodal, in bu makalesine aşağıdaki linkten ulaşılmıştır.

http://pauegitimdergi.pau.edu.tr/Makaleler/1066855563 6CUMHUR\%C4\%B0YET\%C4\%B0N\%20\%C4\%B0LK\%20N \%C3\%9CFUS\%20SAYIMINA\%20G\%C3\%96RE\%20DEN\%C4\%B0ZL\%C4\%B0.pdf 10.03 .2014$.

${ }^{49}$ Osmanlı'da devlet düzeni toprağa endeksliydi. Vergilerin önemli bir kısmı toprak ve hayvanlardan alınırdı. Aynı zamanda ayni vergi alınırdı. Tımar sistemine dayalı olarak tımarlı sipahiler de işin askeri boyutuydu. Tımarlı sipahiler Osmanlı ordusunda en büyük kısmını oluşturmaktaydı. Şehirlilere göre daha dayanıklı olduklarından Osmanlı askerlerinin önemli bir kısmını köylü çocukları oluşturmaktaydı. Tüm bunlardan dolayı çiftçilik Müslüman Osmanlı vatandaşının kaderi gibiydi.

${ }^{50} \mathrm{http}: / /$ ataturkilkeleri.istanbul.edu.tr/wp-content/uploads/2013/03/ydta-12-dinc.pdf 


\section{F.Ü. Sosyal Bilimler Dergisi 2015-25/1}

kaynağı tarım ve hayvancılıktır. Elazı̆̆'da iş sahibi nüfusun \% 83.5'i tarım sektöründe çalışmaktadır. Tarım dışında çalışan nüfus toplam çalışan nüfusun $\% 16.5$ 'ine denk düşmektedir (8.702 kişi). Elazığ'da ikinci sırada yapılan meslek hizmetler sektörüdür. Bu sektörde toplam çalışan nüfusun \%7.2'sini oluşturan 3.797 kişi çalışmaktadır. Ordu bu kategoride en önde gelen iş sektörüdür. Orduda çalışanlar çalışan nüfusun \%6.1'i olan 3.194 kişidir. Elazığ' da sanayi ile uğraşanlar 1.767 kişiyle üçüncü sırada yer almaktadır. Yüzdelik olarak ise toplam çalışan nüfusun \%3.4'ü oranındadır. Ticaretle uğraşan sayısı dördüncü sırada yer almaktadır. Bu grupta çalışanlar toplam çalışan nüfusun \%3.3'üne denk düşmektedir. Beşinci sırada muhtelif olarak tasnif edilen grup yer almaktadır. Bu grupta ye alan 1.012 kişi çalışan nüfusun \%1.9'u oranındadır. Bununla birlikte Elazı̆g' da 467 memur, 89 hâkim, 47 P.T.T memuru ve 393 serbest meslek sahibi bulunmaktadır. Çalışan nüfusun \%0.9'u' memur, \%0.2'si hâkim, \% 0.1'i PTT çalışan, \%0.7'si ise serbest meslek sahibidir. ${ }^{51} 1927$ Nüfus Sayımına göre Elazı ̆̆' da yaşayan insanların \% 62.4'ü işsizdir. Yapılan çalışmalara göre Türkiye'deki pek çok ilde de işsizlik oranı $\% 60$ civarındadır ${ }^{52}$. Elazı̆g nüfusunun \% 37.6's1 ise iş sahibidir. Nüfusun üçte ikisinin işsiz olması il ekonomisi için olumsuz olsa da bu ortalama o dönemi Türkiye genelinde görülen olağan bir istatistik verisidir.

Tablo 11. 1927 Genel Nüfus Sayımına Göre Elazı̆̆g'da Meslekler

\begin{tabular}{|c|c|c|c|c|c|c|c|c|c|c|c|}
\hline İlçeler & Cinsiyet & Tarım & Sanayi & Ticaret & \begin{tabular}{|l} 
Serbest \\
Meslek
\end{tabular} & Memur & Hâkim & Ordu & P.T.T & Muhtelif & $\begin{array}{c}\text { Mesleksiz veya } \\
\text { Mesleği Bilinmeyen }\end{array}$ \\
\hline \multirow{3}{*}{ Merkez } & Erkek & 12.396 & 1.369 & 1.271 & 278 & 328 & 43 & 2.680 & 33 & 592 & 19.894 \\
\hline & Kadın & 8.102 & 183 & 34 & 21 & 6 & 1 & - & 1 & 167 & 31.815 \\
\hline & Toplam & 20.498 & 1.552 & 1.305 & 299 & 334 & 44 & 2.680 & 34 & 759 & 51.709 \\
\hline \multirow{3}{*}{ Baskil } & Erkek & 4.959 & 9 & 8 & 8 & 11 & 32 & 1 & - & 40 & 881 \\
\hline & Kadın & 2.870 & 1 & - & - & - & - & - & F & 1 & 3.984 \\
\hline & Toplam & 7.829 & 10 & 8 & 8 & 11 & 32 & 1 & $F$ & 41 & 4.865 \\
\hline \multirow{3}{*}{ Keban } & Erkek & 588 & 23 & 29 & 15 & 17 & 4 & 23 & 3 & 6 & 764 \\
\hline & Kadın & 531 & - & - & 2 & - & $F$ & - & - & 3 & 1.348 \\
\hline & Toplam & 1.119 & 23 & 29 & 17 & 17 & 4 & 23 & 3 & 9 & 2.112 \\
\hline \multirow{3}{*}{ Maden } & Erkek & 2.390 & 62 & 85 & 42 & 56 & 5 & 160 & 8 & 52 & 2.113 \\
\hline & Kadın & 835 & 2 & 2 & 1 & - & - & - & - & 11 & 4.195 \\
\hline & Toplam & 3.225 & 64 & 87 & 43 & 56 & 5 & 160 & 8 & 63 & 6.308 \\
\hline \multirow{3}{*}{ Palu } & Erkek & 7.200 & 118 & 303 & 25 & 49 & 4 & 330 & 3 & 138 & 8.938 \\
\hline & Kadın & 4.240 & - & 1 & 1 & $F$ & 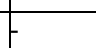 & - & F & 2 & 13.654 \\
\hline & Toplam & 11.440 & 118 & 304 & 26 & 49 & 4 & 330 & 3 & 140 & 22.592 \\
\hline \multirow{3}{*}{ Toplam } & Erkek & 27.533 & 1.581 & 1.696 & 368 & 461 & 88 & 3.194 & 46 & 828 & 32.590 \\
\hline & Kadın & 16.578 & 186 & 37 & 25 & 6 & 1 & - & 1 & 184 & 54.996 \\
\hline & Toplam & 44.111 & 1.767 & 1.733 & 393 & 467 & 89 & 3.194 & 47 & 1.012 & 87.586 \\
\hline
\end{tabular}

Kaynak: BİUM 1927 Umumi Nüfus Tahriri, Fasikül I, Hüsnütabiat Matbaası, Ankara 1929, s. 29, 189-190.

1927 nüfus sayımına göre Elazığ'da çalışan nüfusun \% 32.2'sini kadınlar (17.018 kişi), 67.8'ini ise erkekler (35.795 kişi) oluşturmaktadır. Elazığ' da tarım dışında 439 kadın çalışmaktadır. $\mathrm{Bu}$ da çalışan nüfusun \% 0.8'ine denk düşmektedir. Elazı̆̆ genelinde ordu dışındaki tüm sektörlerde çalışan kadın vardır. Tarım dışı sektörde kadın varlığı ilçelerde çok azdır. Maden'de sanayide 2, ticarette 2 ve serbest meslekte 1, Palu'da ticarette 1 ve serbest meslekte 1, Keban'da serbest meslekte 2, Baskil'de sanayide 1 kadın çalışmaktadır. Elazığ genelinde meslek kollarının en

\footnotetext{
${ }^{51}$ BİUM 1927 Umumi Nüfus Tahriri, Fasikül I, Hüsnütabiat Matbaas1, Ankara 1929, s. 29, 189-190.

${ }^{52}$ Çorum'da 1927 itibarıyla işsiz nüfus toplam nüfusun 3/2'si oranındadır. Ayrıntı için bkz. Kodal, A.g.m, s. 249. Iğdır'da da nüfusun 2/3'ü işsizdir. Bkz. Kara-Yuca, A.g.m, s. 199. Bu durum Kars için de geçerlidir. Bkz. Nebahat Oran Arslan-İlyas Topçu, "Cumhuriyet Döneminde Kars’ta Nüfus”, Karadeniz Incelemeleri Dergisi, S.6/2012, s. 100. Dersim'de nüfusun \%66.3'ü işsizdir. Ayrıntı için bkz. Savaş Sertel, "Türkiye Cumhuriyeti'nin İlk Nüfus Sayımına Göre Dersim Bölgesinde Demografik Yapı”, Fırat Üniversitesi Sosyal Bilimler Dergisi, C. XXIV, S. I, Elazı̆̆ 2014, s. 279. Bodrum'da nüfusun \%59.15'i işsizdir. Ayrıntı için bkz. Tahir Kodal, "Atatürk Döneminde Bodrum'un Nüfus Yapısı(1923-1938)", Süleyman Demirel Üniversitesi Fen Edebiyat Fakültesi Sosyal Bilimler Dergisi, Mayıs 2008, S. 17, s.89. Daha gelişmiş olan bir coğrafyada bulunan Zonguldak'ta ise işsizlik oranı \%49'dur. Ayrıntı için bkz. Hamdi Genç, "Cumhuriyet'in İlk Yillarında Zonguldak’ta Nüfus, Ticaret ve Sanayi(1920-1932)", Zonguldak Kara Elmas Üniversitesi Sosyal Bilimler Dergisi, C. VI, S. 12, Zonguldak 2010, s. 141.
} 
yaygın olduğu yer il merkezidir. İkinci sırada Palu, üçüncü sırada Baskil, dördüncü sırada Maden ve son sırada Keban yer almaktadır. Çalışmayan nüfusun \%62.8'i kadın, \%37.2'si erkektir.

İlde sanayi, ticaret ve serbest meslek sektörlerinde çalışan çok az insan vardır. Bu sektörler bir ilin ekonomik gelişmesinde lokomotif sektörlerdir. Tarım üretimi ilkel ve kısıtll, sanayi ve ticareti gelişmemiş bir ilin kısa ve orta vadede gelişebilmesi mümkün değildir. 1927'de Elazığ' da alanında uzmanlaşmış kalifiye insan sayısının da çok az olduğu düşünülecek olursa kalınma bu dönemde Elazığ için imkânsızla eş anlamlıdır. 1927'de orduda çalışan insan sayısı 3.194 kişidir. Bu sayı tüm sektörler tek tek ele alındığında ikinci sırada yer almaktadır. Bu veriler ilde asayişsizliğin hâkim olduğunu gösterir. Bununla birlikte bölgede olası bir isyan için tedbir amacıyla da asker sayısı yüksek tutulmuş olabilir. ${ }^{53}$ İl nüfusu ile kıyaslanırsa memur sayısı da çok azdır. İncelenen dönem itibarıyla ilde kamu ve özel sektörde yatırım yapılabilmesi mümkün değildir. İlde tarım dış1 sektörlerde çalışan kadın sayısı çok azdır.

\section{Sonuç}

1927 nüfus sayımı sonuçlarına göre Elazığ'da 140.400 kişi yaşamaktadır. Bu dönemde Elazı̆̆ nüfusunun \%18.6'sı kentlerde, \%81.4'ü kırsalda yaşamaktadır. 1927'de Türkiye'de km² ye 17.89 kişi düşerken, Elazı ğ' da Km² ye 13.70 kişi düşmektedir. 1927 yılında Elazı ğ'da 2.000 gayrimüslim yaşamaktadır. 1927'de Elazığ' da 1.781 özürlü bulunmaktadır. İlde okuryazarlık oranı \%4.85'tir. Nüfusun \%62.4'ü işsiz veya mesleği bilinmeyen grubunda yer almaktadır. Çalışan nüfusun \% 83.5'i tarım sektöründe çalışmaktadır. Bu veriler bile ilin kalkınamadığını ve uzun yıllar boyunca da kalkınamayacağının göstergesidir. Kalkınamamışlık sadece endüstrileşmemek anlamında değil her anlamdadır. Çünkü ilde yaşayan nüfusun nitelikleri de yetersizdir. İlde yetişmiş insan gücü çok sinırlıdır. Bu da kalifiye insandan çok kas gücüne dayalı iş yapacak nüfusun olduğunun bir göstergesidir. 1927 verileri il nüfusunun her türlü yatırıma muhtaç olduğunu göstermiştir. Özellikle eğitim alanında çok fazla yatırıma ihtiyaç olduğu görülmüştür. Sanayi, endüstri ve ticaret sektörlerinin de devlet yatırımları olmadan gelişemeyeceği de ortaya çıkmıştır. Zaten modern nüfus sayımlarının amacı da nüfusun gelecekteki ihtiyaçlarının hangi alanlar da olacağı ve bu alanlara yapılacak yatırımların tespitidir. Bu çalışma Cumhuriyet yönetimi için en büyük eksikliklerden birinin uzun savaşlardan yıpranan Anadolu halkının sermaye birikimine sahip olmaması ve özel sektörün özellikle Doğu Anadolu'da uzun yıllar var olamayacağını da göstermiştir.

\section{Kaynakça}

AKSIN, Ahmet; 19. Yüzyllda Harput, Elazığ 1999.

Anabritannica, Elazığ Maddesi, C. XI, İstanbul 1994, s. 161-162.

ARSLAN, Nebahat Oran -İlyas TOPÇU; "Cumhuriyet Döneminde Kars'ta Nüfus", Karadeniz Incelemeleri Dergisi, S.6/2012, s.87-124.

ARSLANTAŞ, Yüksel; Tarih Öncesi Dönemde Elazı̆̆, Elazı̆̆ 2013.

ATASOY, Ahmet-M. Dursun Çitçi; “Elazığ Şehri’nin Nüfus Özellikleri ve Çevrenin Toplum Sağlı̆̆ı Üzerindeki Etkisi", Turkish Studies International Periodical For the Languages, Literature and History of Turkish or Turkic, Volume 4/3 Spring 2009, s. 197-226.

Başbakanlık İstatistik Umum Müdürlüğü; 1927 Umumi Nüfus Tahriri, Fasikül I, Hüsnütabiat Matbaası, Ankara 1929.

Başbakanlık İstatistik Umum Müdürlüğü; 1935 Genel Nüfus Sayımı, Ankara 1937.

Başvekâlet Merkezi İstatistik Müdüriyeti Umumiyesi, 1927 Umumi Nüfus Tahriri, Türk Ocakları Merkez Heyeti Matbaası, Ankara 1928.

\footnotetext{
${ }^{53}$ Türkiye'de askerlik görevi belirli bir süreliğine ve mecburi olarak yapılmaktadır. Bu nedenle askerler maaş almazlar. Tablodaki ordu çalışanları maaş karşılığı askerlik yapan subay ve astsubayları kapsamaktadır 1927'de İlde 3.194 komutan olduğuna göre asker sayısı çok daha fazladır. Bu arada Şeyh Sait İsyanı 1925'te sona etmiştir. 1927'de Hükümetin ihtiyatlı olması doğaldır.
} 


\section{F.Ü. Sosyal Bilimler Dergisi 2015-25/1}

BiLGí, Nejdet ; “Osmanlı Devleti’nin 1917 Yı1ı Yabancı Nüfusu”, Tarih Incelemeleri Dergisi, C. XXV, S. I, Temmuz 2010, s. 101-146.

CUINET, Vital; Turque D'asle, Paris 1892

BAŞOL, Koray; Demografi(Genel ve Türkiye), İzmir 1984.

BULDUK, Abdulgani; El-Cezire'nin Muhtasar Tarihi, Yayına Hazırlayanlar: Mustafa Öztürk, İbrahim Yılmazçelik, Elazığ 2004,

DANIŞ, Didem; “Demografi: Nüfus Meselelerine Sosyolojik Bir Bakış", Ders Notları, s. 1-21.

D.İ.E; 1965 Genel Nüfus Sayımı, İdari Bölünüs,, Ankara 1968.

DINNÇER, Sinan; “Ilk Gurbetçiler: Harput'tan ABD'ye Emek Göçü”, Geçmişten Geleceğe Harput Seтроzуити(23-25 Mayıs 2013) Bildiri Kitabl, C. I, s. 307-319.

GENÇ, Hamdi; “Cumhuriyet'in İlk Yıllarında Zonguldak'ta Nüfus, Ticaret ve Sanayi(1920-1932)", Zonguldak Kara Elmas Üniversitesi Sosyal Bilimler Dergisi, C. VI, S. 12, Zonguldak 2010, s. 137-152.

GÖK, Yaşar-Alperen, KAYSERILİ; "Cumhuriyet Döneminde(1927-2008) Erzurum İlinin Kır-Şehir Nüfus Değişimi.”, Doğu Coğrafya Dergisi, S. XXIV, s. 1-24.

HAMIDULLAH, Muhammad; İslam Peygamberi, C. I, İstanbul 1995.

KARA, Hidayet-Sami YUCA; "Cumhuriyetin İlk Nüfus Sayımına göre Iğdır'da Demografik Yapı", History Studies, C. 2/3, 2010, s. 189-200.

KARAL, Enver Ziya; Osmanlı Imparatorluğunda İlk Nüfus Sayımı 1831, Ankara 1997.

KARPAT, Kemal; Osmanlı Nüfusu(1830-1914), Çev. Bahar Tırnakçı, Timaş yayınları, İstanbul 2010.

KODAL, Tahir; “Atatürk Döneminde Bodrum'un Nüfus Yapıs1(1923-1938)", Süleyman Demirel Üniversitesi Fen Edebiyat Fakültesi Sosyal Bilimler Dergisi, Mayıs 2008, S. 17, s.77-100.

KODAL, Tahir; “Türkiye Cumhuriyeti'nin İlk Genel Nüfus Sayımında Çorum Vilayeti'nin Nüfus Özellikleri”, Firat Üniversitesi Sosyal Bilimler Dergisi, C. XIX, S. I, Elazı ̆ 2009, s. 233-258.

KÖSE, Mustafa; 1927 Nüfus Sayımı ve Sonuçlarının Değerlendirilmesi, Afyon Kocatepe Üniversitesi Sosyal Bilimler Enstitüsü, Yayınlanmamış Yüksek Lisans Tezi, Afyonkarahisar 2010.

Milli Eğitim Bakanllğı İslam Ansiklopedisi, Elazığ Maddesi, C. IV, İstanbul 1979, s. 221-223.

SERTEL, Savaş; “Türkiye Cumhuriyeti’nin İlk Nüfus Sayımına Göre Dersim Bölgesinde Demografik Yapı”, Firat Üniversitesi Sosyal Bilimler Dergisi, C. XXIV, S. I, Elazı̆̆ 2014, s. 269-282.

Şemsettin Sami; Kamûsü'l-Âlâm, Mihran Matbaası, İstanbul 1891, C. VI.

TAMER, Aytül -Alanur ÇAVLIN BOZBEYOĞLU; “ 1927 Nüfus Sayımının Türkiye'de Ulus Devlet İnşasındaki Yeri: Basında Yansımalar.”, Nüfusbilim Dergisi|Turkish Journal of Population Studies, 2004, S. 26, s. $73-88$.

Türkiye Diyanet Vakfi İslam Ansiklopedisi, Elazı̆̆ Maddesi, C. X, İstanbul 1994, s. 551-554.

YILDIRIM, Recep; "Harput/Elazığ Yöresinin Tarihi Coğrafyası", Geçmișten Geleceğe Harput Sempozyuти(23-25 Mayıs 2013) Bildiri Kitabl, C. I, s. 297-306.

YUCA, Sami; "Cumhuriyet Döneminin İlk Nüfus Sayımına Göre Muş İlinin Nüfus Özellikleri.”, Akademik Bakış Dergisi, S. 24(Nisan, Mayıs, Haziran) 2011, Celalabat-Kırgızistan, 2011, s. 1-31.

1310 Tarihli Mamuratül Aziz Vilayet Salnamesi

http://ataturkilkeleri.istanbul.edu.tr/wp-content/uploads/2013/03/ydta-12-dinc.pdf 20.05.2014

http://pauegitimdergi.pau.edu.tr/Makaleler/1066855563 6CUMHUR\%C4\%B0YET\%C4\%B0N\%20\%C 4\%B0LK\%20N\%C3\%9CFUS\%20SAYIMINA\%20G\%C3\%96RE\%20DEN\%C4\%B0ZL\%C4\%B0.pdf 28.05 .2014 